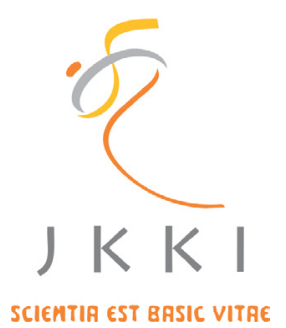

Jurnal Kedokteran dan Kesehatan Indonesia

Indonesian Journal of Medicine and Health

Journal homepage : www.journal.uii.ac.id/index.php/JKKI

\title{
Split Thickness Skin Grafts (STSG): Approach in necrotising fasciitis, a rare case report
}

Agung Widianto ${ }^{1}$, Wahyu Kartiko Tomo*1

${ }^{1}$ Department of Surgery, Faculty of Medicine, Universitas Gadjah Mada, Yogyakarta, Indonesia

Case Report

\begin{tabular}{|c|c|}
\hline & \\
\hline nin & \multirow{4}{*}{$\begin{array}{l}\text { Treatment of necrotising fasciitis including systemic antibiotic and radical } \\
\text { surgical debridement is often resulting in large wounds that need to be } \\
\text { closed using methods such as split-thickness skin grafts, local flaps, or } \\
\text { guided tissue regeneration procedures. In this case report, } 53 \text { year-old } \\
\text { male was diagnosed with necrotising fasciitis and treated surgically. } \\
\text { The wound was treated initially with extensive debridement, wound } \\
\text { treatment with platelet-rich plasma and finally closing the wound with } \\
\text { split-thickness skin grafts. Split-thickness skin grafts can provide fast } \\
\text { recovery and functional skin. }\end{array}$} \\
\hline & \\
\hline & \\
\hline 3 & \\
\hline & \multirow{2}{*}{$\begin{array}{l}\text { Pengobatan necrotising fasciitis termasuk antibiotik sistemik dan } \\
\text { debridemen bedah radikal sering mengakibatkan luka besar yang perlu } \\
\text { ditutup menggunakan metode seperti cangkok kulit split-tebal, flap lokal, } \\
\text { atau prosedur regenerasi jaringan sesuai dengan pedoman. Dalam laporan } \\
\text { kasus ini, pria } 53 \text { tahun didiagnosis dengan necrotising fasciitis dan } \\
\text { dirawat dengan pembedahan. Luka awalnya dirawat dengan debridemen, } \\
\text { perawatan luka dengan plasma kaya trombosit dan akhirnya menutup } \\
\text { luka dengan cangkok kulit split-tebal. Cangkok kulit split-thickness dapat } \\
\text { memberikan pemulihan yang cepat dan kulit fungsional. }\end{array}$} \\
\hline & \\
\hline
\end{tabular}

\section{INTRODUCTION}

Necrotising fasciitis is a rapidly progressive, life-threatening infection and a real infectious disease emergency. Despite much clinical experience, the management of this disease remains suboptimal, with mortality rates remains approximately $30 \%{ }^{1}$

Necrotising fasciitis rarely presents with apparent signs and symptoms. Delays in diagnosis enhance mortality. Therefore, successful patient care depends on the physician's understanding and index of suspicion. Prompt surgical debridement, fluid and electrolyte management, and also analgesia are mainstays of therapy. ${ }^{2}$ Intravenous antibiotics, and hyperbaric oxygen therapy are frequently employed in the treatment of necrotising fasciitis, but their efficacy has not been rigorously established. Improved understanding of the diagnosis, debridement and skin grafting of necrotising fasciitis has revealed new targets for rationally designed therapies to improve morbidity and mortality. ${ }^{3}$

\section{CASE REPORT}

A 53-year-old previously was surgically treated for necrotising fasciitis. The patient was presented to emergency department where a local infection was diagnosed. The skin of the right lower abdomen and right upper thigh was erythematous, warm, and tender (Figure 1). He was started on broad-spectrum intravenous antibiotics and underwent surgical debridement 
and drainage. The Providencia stuartii test was positive, and the patient was immediately taken in for surgery.

Clinical findings were necrotic skin and subcutaneous tissue in the left lower abdomen and left upper thigh. All necrotic tissue was removed until viable macroscopic tissue was found in all areas. At that point, the patient was referred to the ward with a sepsis. The systolic blood pressure was normal, with a high leucocytosis (38.300/uL), anemia $(7.7 \mathrm{mg} / \mathrm{dL})$, hypoalbuminemia $(2.1 \mathrm{mg} / \mathrm{dL})$ and abnormal electrolyte.

The patient was not intubated and was put on with transfusion, meropenem, metronidazole, fentanyl, pantoprazole, and ranitidine. The wound was left open in one month. The wound was treated with platelet-rich plasma.

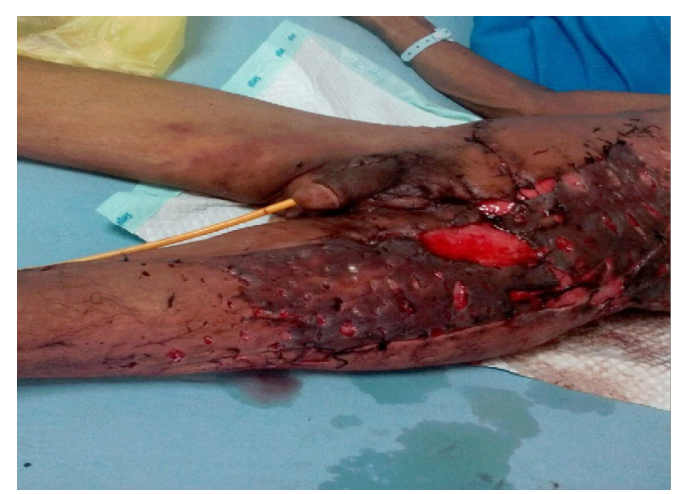

Figure 1. Necrotising fasciitis

The wound was examined in thirty days to evaluate the granulation (Figure 2). Thirty days after debridement, we already did the splitthickness skin grafts (STSG). The patient was referred to ICU. Postoperatively, the patient stabilised rapidly. The patient was treated with nasal oxygen, antibiotic and analgetic. The patient returned to the ward (day 3) in good condition.

The patient was immobilised in fifteen days. The day-5 of the examination revealed the awaited peach coloured appearance of regenerated neodermis could be found almost one hundred percents. We reevaluate the STSG at day 5, 7, 11, 15. (Figure 5, 6, 7, 8)

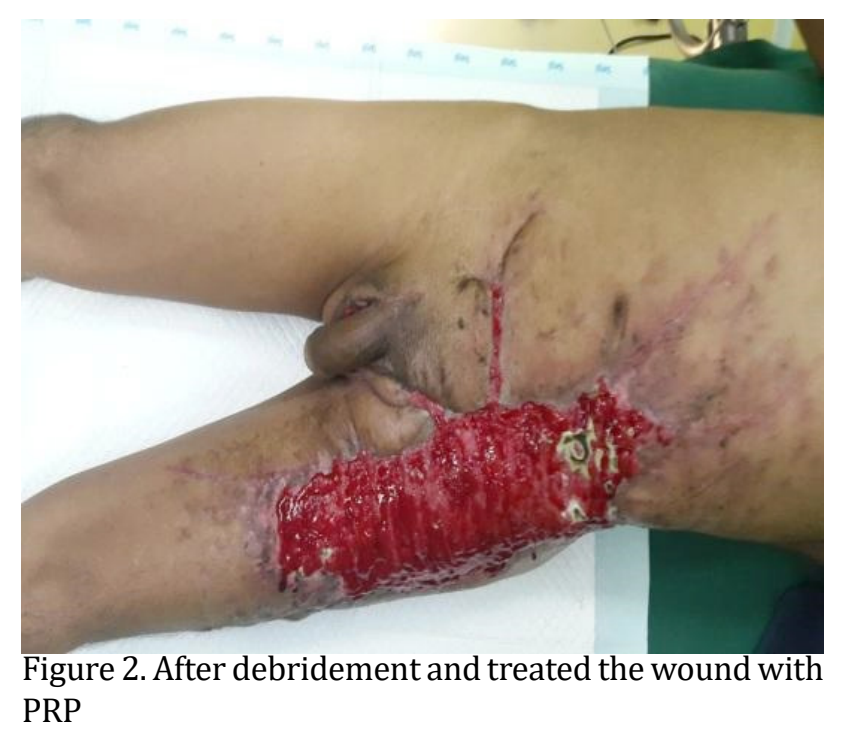




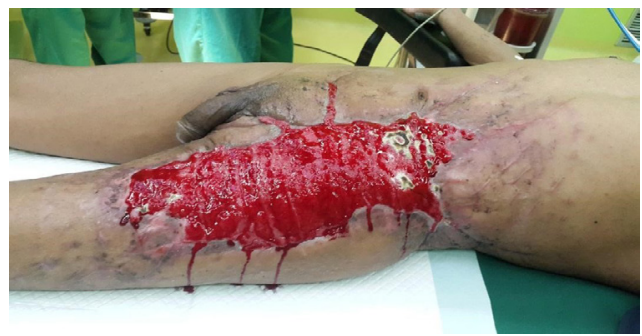

Figure 3. Pre Operation

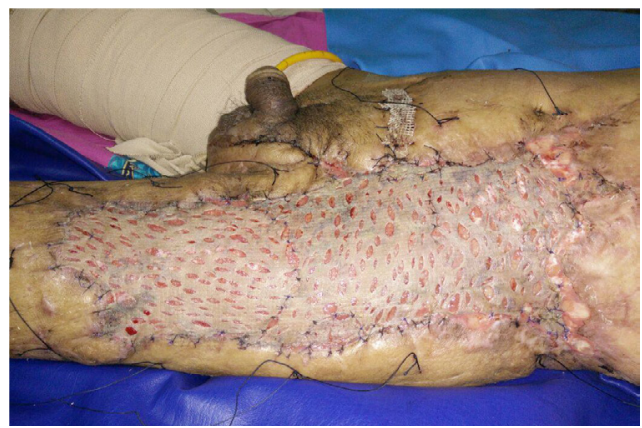

Figure 5. Post Operation Day 5

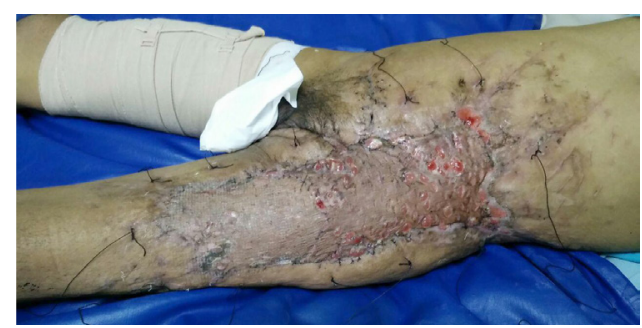

Figure 7. Post Operation Day 11

The STSG was covered with tule, flappy gauze with $\mathrm{NaCl} 0.9 \%$ moist and elastic bandage that had been done previously. At day-5, the wound was examined, and the STSG was found to be healing well. The transplanted wound matured

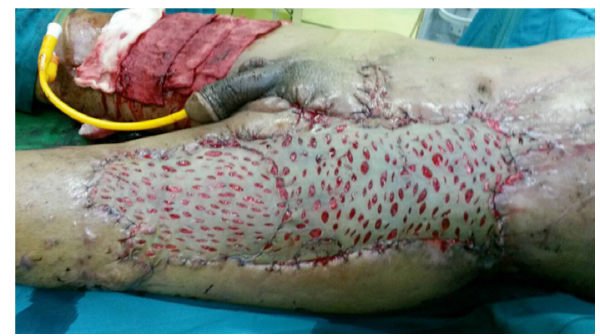

Figure 4. Post Operation Day 0

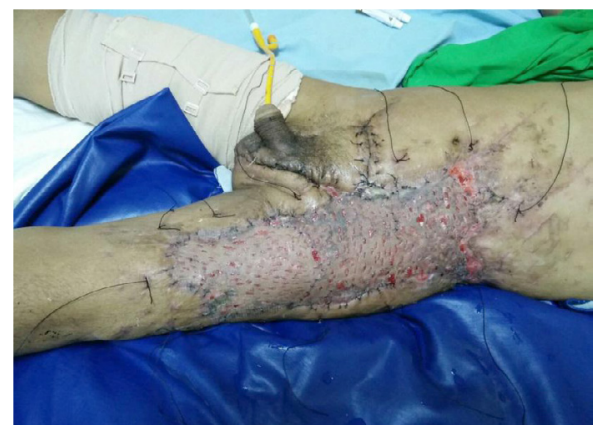

Figure 6. Post Operation Day 7

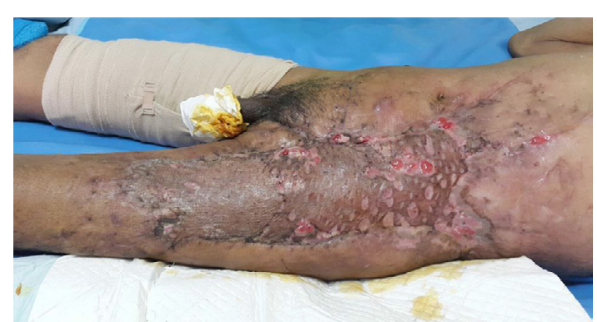

Figure 8. Post Operation Day 15

subsequently and the patient was discharged to home on day-15. The patient returned to control the STSG wound in a day-25, it tooke one hundred percents (Figure 9).

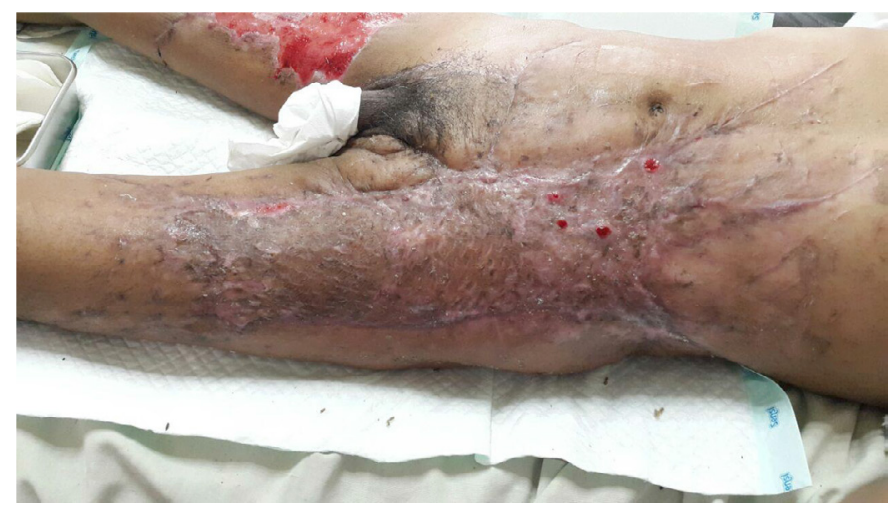

Figure 9. Post Operation Day 25 


\section{CAUSE AND RISKFACTORS OF NECROTISING FASCIITIS}

Most cases of necrotising fasciitis are bacterial in nature, with other organisms such as fungi being responsible only in rare cases. ${ }^{1}$ Bacterial necrotising fasciitis is usually subdivided into two categories. Type I disease can be described as a synergistic polymicrobial infection involving both aerobic, and non-anaerobic bacteria and streptococci species other than serogroup A. ${ }^{2}$ Infection by non-anaerobic bacteria leads to tissue hypoxia, encouraging subsequent colonisation and infection by anaerobic organisms which exacerbates the infection and contributes to its rapid spread. ${ }^{1}$ In contrast, type II necrotising fasciitis is a monomicrobial infection only, involving group A streptococci bacteria. $^{2}$

While anyone with an infection may, in theory, develop necrotising fasciitis, in practice the majority of patients with necrotising fasciitis (82\%) have an immunosuppressive condition such as diabetes mellitus or renal insufficiency, have a history of alcohol abuse or are taking immunosuppressive drugs for cancer. ${ }^{1,4}$ Diabetes mellitus seems to be one of the highest risk factors for the disease, with $57 \%$ of necrotising fasciitis patients in one study reported to be diabetic. $^{5}$

Approximately half of all the patients contracting necrotising fasciitis have a history of skin injury, while $25 \%$ have experienced blunt trauma. ${ }^{5}$ Infections originating in the deep tissues or bones are also a likely source of the disease, as the infection may progress rapidly with no outward visible signs, reaching a critical stage before becoming apparent. ${ }^{1}$ Although the condition can strike an individual of any age, incidence appears to increase with age, and is also more common in men. ${ }^{5}$

Necrotising fasciitis is a life-threatening subcutaneous soft-tissue infection that may extend to the deep fascia, but not into the underlying muscle. The causal organisms may be aerobic, anaerobic, or mixed flora. Two main clinical forms exist. Type I necrotizing fasciitis is a polymicrobial infection with an anaerobicsuch as
Bacteroides or Peptostreptococcus and a facultative anaerobic such as an Enterobacteriaceae or nongroup A streptococcus. ${ }^{6}$

Type II necrotising fasciitis is the most commonly a monomicrobial infection with Streptococcus pyogenes (group A streptococci). Other infectious etiologies may rarely cause a monomicrobial necrotising infection that may be associated with specific exposures or risk factors (e.g., freshwater exposure associated with Aeromonas hydrophila, saltwater exposure or consumption of raw oysters related with Vibrio vulnificus) ${ }^{6}$

Type I disease tends to occur in individuals with some form of immunosuppression or chronic disease, while type II disease can occur in any individual of any age and even in the absence of any medical complications. ${ }^{7}$

\section{PATHOPHYSIOLOGY}

Microbial invasion of the subcutaneous tissues occurs either through external trauma or direct spread from a perforated viscus (particularly colon, rectum) or urogenital organ. Bacterial growth within the superficial fascia releases a mixture of enzymes and endo and exotoxins causing the spread of infection through this fascia. ${ }^{8}$ This process results in poor microcirculation, ischaemia in affected tissues, and ultimately, cell death and necrosis.

Thrombosis of small veins and arteries passing through the fascia causes profound skin ischaemia. This skin ischaemia is the fundamental process for the soft tissue presentation of necrotising fasciitis as it progresses. Importantly, during the early pathological stages, anormallooking skin is seen, despite extensive infection of the underlying fascia. Haemorrhagic bullae, ulceration, and skin necrosis subsequently manifest with further involvement of the deeper structures. $^{5}$

The initial clinical skin findings underestimate the tissue infection present, although thrombosis of penetrating vessels to the skin is the crucial feature in the pathology of necrotising soft tissue infection. Thrombosis of large numbers of dermal capillary beds must occur before skin 
changes suggestive of necrosis occur. ${ }^{7}$

\section{TREATMENT}

Early diagnosis, aggressive resuscitation, surgical debridement, antibiotic therapy, supportive intensive care and split-thickness skin grafts are necessary for managing patients with necrotising fasciitis. Effective communication between the intensivist, surgeon, anaesthetist and microbiologist is essential. ${ }^{3}$

\section{DISCUSSION}

Necrotising fasciitis affects the tissue through thrombosis of skin microcirculation, which results in necrosis, liquefaction of fat, and destruction of muscles. In the presented case, the large wound of the left abdomen and the left upper thigh were also involved, resulting in profound necrotising fasciitis. For such defects, wound coverage achieved by using meshed split thickness skin grafts. This provides effective wound closure and imposes limited morbidity.2However, there are several drawbacks both in terms of function (i.e., wound contracture and hypertrophic scarring) and the cosmetic result (meshed grafts usually leave an unsightly "fish-net" appearance). In the protocol described in the presented case, the affected area was initially treated with debridement and antibiotics to control infection. ${ }^{8}$

One month after discharge, the patient had a good cosmetic and functional result. No sign of hypertrophic scarring was seen in the area covered. The final clinical appearance and physical function of the grafted wound were regarded as excellent with smooth and viable skin.

Although the original report by Burke et al. noted takes rates of $95 \%$ to $100 \%$ of splitthickness skin grafts on artificial dermis, subsequent authors have not been as successful. Improvements take rate has been reported with the use of negative pressure wound therapy. 8In this case we did not use negative pressure wound therapy procedure.

Tipically, dermal regeneration usually takes place over 3-6 weeks if local conditions remain optimal, and an additional four days is necessary for epidermal take. In the present case, proper dermal regeneration was achieved after 15 days with excellent take of the epidermal layer after skin grafting. ${ }^{2}$

\section{CONCLUSION}

We believe that this is a safe way to proceed when the initial debridement is appropriately performed. Initial extensive debridement with a short delay to wound closure with a plateletrich plasma device provides rapid recovery and excellent skin grafting results for the patient in addition to be a safe procedure. Split-thickness skin grafts can provide fast recovery and functional skin.

\section{CONFLICT OF INTEREST}

None declare.

\section{Acknowledgement}

None declare.

\section{REFERENCES}

1. Young MH, Engleberg NC, Aronoff DM. Necrotizing fasciitis: Pathogenesis and treatment. Literature Review in Expert Review of Anti-infective Therapy. 2005;3(2):27994.

2. Steiner KL, Petri WA. Necrotizing fasciitis. BMJ Best Practice. 2019.

3. Stevens DL, Aldape MJ, Bryant AE. Necrotizing fasciitis, gas gangrene, myositis and myonecrosis. Infectious Diseases. 2017;1(4):95-103.

4. Black JM, Black SB. Surgical wounds, tubes, and drains. In: Baranoski S, Ayello EA, eds Wound Care Essentials: Practice Principles 2nd Edition Lippincott Williams \& Wilkins, Ambler PA. 2008.

5. Sarani B, Strong M, Pascual J, Schwab CW. Necrotising fasciitis: Current concepts and review of the literature. Journal of the American College of Surgeons. 2009;208(2):27988.

6. Cheung JPY, Fung B, Tang WM, Ip WY. A review of necrotising fasciitis in the extremities. Hong Kong Medical Journal. 
JKKI 2019;10(1):91-96

2009;15(1):44-52.

7. Hung CC, Chang SC, Lin SF, Fang CT, Chen YC, Hsieh WC. Clinical manifestations, microbiology and prognosis of 42 patients with necrotizing fasciitis. Journal of the Formosan Medical Association. 1996;95(12):91722.

8. Shimizu T, Tokuda Y. Necrotizing fasciitis. Internal Medicine Journal. 2010;49(12):1051-7. 